\title{
Autologous serum for ocular surface diseases
}

\author{
Soro autólogo para doenças da superfície ocular
}

\author{
GuilhermeGoulart Quinto \\ MauroCampos ${ }^{2}$ \\ Ashley Behrens $^{3}$
}

\begin{tabular}{|l|}
\hline ABSTRACT \\
\hline Autologous serum has been used to treat dry eye syndrome for many years. \\
It contains several growth factors, vitamins, fibronectin and other com- \\
ponents that have been considered important for corneal and conjunctival \\
integrity. Serum eye drops are usually prepared as an unpreserved blood \\
solution. The serum is by nature well tolerated and its biochemical \\
properties are somewhat similar to natural tears. Autologous serum eye \\
drops have been reported to be effective for the treatment of severe dry \\
eye-related ocular surface disorders (Sjögren's syndrome), and also other \\
entities such as superior limbic keratoconjunctivitis, graft-versus-host \\
disease, Stevens-Johnson syndrome, ocular cicatricial pemphigoid, re- \\
current or persistent corneal erosions, neurotrophic keratopathy, Mooren's \\
ulcer, aniridic keratopathy, filtering blebs after trabeculectomy, and post- \\
keratorefractive surgery. The purpose of this study is to review the recently \\
published literature on ocular surface diseases treated with human \\
autologous serum eye drops.
\end{tabular}

Keywords: Corneal diseases/therapy; Conjunctival diseases/therapy; Lacrimal apparatus/ abnormalities; Serum; Ophthalmic solutions/therapeutic use
Trabalho realizado no Wilmer Ophthalmological Institute, Baltimore (MD) - USA.

${ }^{1}$ Fellow in Cornea and Refractive Surgery at the Wilmer Ophthalmological Institute, The Johns Hopkins University School of Medicine - Baltimore (MD) - USA.

${ }^{2}$ Livre Docente, Professor Adjunto do Departamento de Oftalmologia da Universidade Federal de São Paulo UNIFESP - São Paulo (SP) - Brasil.

${ }^{3}$ Professor at the Wilmer Ophthalmological Institute, The Johns Hopkins University School of Medicine Baltimore (MD) - USA.

Os autores não possuem interesse comercial ou financeiro em nenhum produto mencionado no presente manuscrito.

Endereço para correspondência: Ashley Behrens, M.D. The Wilmer Eye Institute 600 North Wolfe St - 255 Woods Building. Baltimore, MD 21287-0005, USA. E-mail: abehrens@jhmi.edu

\section{INTRODUCTION}

The ecosystem of the ocular surface depends on the dynamic interactions of healthy adnexa (eyelid margins), adequate blink rate, normal tear production, and ocular surface tissue, consisting of cornea and conjunctiva $^{(1)}$. Tears have a significant importance in the stability of the corneal and conjunctival epithelia due to the interdependence between the various structures comprising the ocular surface. The corneal demand for glucose, electrolytes, and amino acids is supplied by the aqueous humor, and growth factors, vitamins and neuropeptides secreted by lacrimal glands, which support proliferation, migration, and differentiation of the ocular surface epithelia. Tears have lubricating and mechanical properties, but also epitheliotrophic and antimicrobial effects. A reduction of epitheliotrophic factors compromises the integrity of the surface epithelia. This can lead to epithelial defects that tend to persist and progress as a result of the compromised wound healing process( ${ }^{(2)}$.

Conventional therapeutic options include intensive artificial tear supplements, punctal occlusion, contact lenses, and appropriate management of adnexal disease. The most frequent therapy utilized to treat ocular surface disorders is artificial tear eye drops. However, none of the commercially available artificial tear preparations includes essential tear components such as growth factors, vitamins, and immunoglobulins. Another drawback of artificial tears is the fact that they often contain preservatives, stabilizers, and other additives, which potentially induce toxic or allergic 
reactions ${ }^{(3)}$. Despite maximal conventional therapy, there is a cohort of patients who still have persistent symptoms and signs. Such patients may have more serious ocular surface disorders with significant visual impairment and disability.

Autologous serum eye drops have been recommended for the treatment of several ocular surface disturbances, such as Sjögren's syndrome-related tear deficiency, non-Sjögren's tear deficiency associated with graft-versus-host disease, neurotrophic keratitis, persistent epithelial defects, superior limbic keratoconjunctivitis, as well as a supportive measure in ocular surface reconstruction ${ }^{(4)}$. Its utilization in Ophthalmology arose out of the need of finding lacrimal substitutes which, in addition to lubricating the ocular surface, were able to provide other components of tears that are reduced in ocular surface disease $^{(5)}$. Human serum contains substances such as epidermal growth factor, vitamin $\mathrm{A}$, transforming growth factor- $\beta$, fibronectin, and cytokines normally found in tears. These factors are important for maintaining a healthy corneal and conjunctival epithelium ${ }^{(4)}$. This review summarizes the recently published literature on the ocular surface diseases treated with autologous serum.

\section{First trials}

The rationale for the topical use of autologous serum is based on the premise that chemotactic and growth factors present in tears are also present in patient's own serum. Moreover, the biochemical properties of the serum are similar to that of normal tears. Fox et al. ${ }^{(6)}$ initially described the benefits of autologous serum application in dry eyes in patients with Sjögren's syndrome. However, the lack of knowledge about its mechanism of action at the ocular surface level kept its utilization in clinical practice from growing until the end of the decade, when Tsubota et al. ${ }^{(7)}$ evaluated the efficacy of autologous serum drops diluted with saline in the treatment of 12 patients with Sjögren's syndrome. The authors used the parameters of fluorescein and rose bengal staining, tear break-up time, and subjective symptomatic scores to assess efficacy. Improvement occurred in all parameters, which were measured at the second and fourth week after autologous serum eye drop application. The main drawback of this study was related to its non-comparative nature, where the patients used autologous serum in addition to artificial tears.

\section{Human serum properties}

It is known that autologous serum contains some components involved in the proliferation, migration and differentiation of the ocular surface epithelial cells. It is believed that many serum components may have some trophic effects on the surface epithelial cells due to their action on epithelial dynamics, modeling the proliferation of epithelial cells in the limbus and cornea ${ }^{(1)}$. In vitro studies with conjunctival epithelial cells have proved an effect of autologous serum on the expression of mucins, mainly MUC1, regulated by EGF receptors in the cup shaped cells ${ }^{(7)}$. The effect of autologous serum on the ocular surface is determined by its numerous properties. Serum exhibits characteristics which are very similar to those of tears regarding $\mathrm{pH}$ and osmolarity. Like tears, it contains abundant growth factors and bactericidal components, which provide the nutritional factors necessary to maintain cellular viability in the epithelial repair processes, and bactericidal components to reduce the risk of contamination and infection ${ }^{(8)}$. Autologous serum therapy produces a temporary beneficial effect on the epithelial surface which disappears when its application is interrupted ${ }^{(7)}$. The efficacy of this treatment in persistent epithelial defects begins to be noticed at the second week of follow-up, although a subjective improvement of patients begins about the second day of treat$\operatorname{ment}^{(9)}$.

Of all human serum components, it is believed that the most important for ocular surface are: epithelial growth factor (EGF), transformer growth fibroblast $\beta$-factor (TGF- $\beta$ ), vitamin A, fibronectin, albumin, $\alpha-2$ macroglobulin, the platelet-derived growth factor (PDGF-AB), hepatocyte growth factor, neuropeptides such as substance $\mathrm{P}$ and the insulinlike growth factor. Accordingly, EGF accelerates the migration process of epithelial cells, and has anti-apoptotic effects. This factor is present in the basal as well as reflex lacrimal secretion, with a slightly lower concentration to the one it has in autologous serum. TGF- $\beta$ is involved in epithelial and stromal repair processes, with its concentration in serum being three times more than the concentration found in tears. Vitamin A seems to prevent squamous metaplasia processes of epithelium. Its concentration in serum is much higher to that found in tears. On the other hand, proteins such as albumin have proved to have anti-apoptotic activity, while $\alpha-2$ macroglobulin exhibits anti-collagenase activity. Fibronectin is one of the most important factors in cellular migration, with its concentration in serum being significantly above that found in tears.

Autologous serum contains neuronal factors such as substance P and insulin-1-type growth factor, which seem to play a role in the migration and adhesion of the corneal epithelium to its stroma. PDGF-AB is one of the 5 known isoforms of platelet-derivated growth factors and is activated intracellularly and secreted by the alpha granules of platelets after its activation, enhancing mitosis and scarring. In addition, autologous serum contains immunoglobulines such as IgG, IgA, lysozyme and supplemental factors that provide bactericide and bacteriostatic effects ${ }^{(5)}$. Table 1 shows the comparative relationship between concentrations of the main epitheliotrophic factors found in tears and in autologous serum.

\section{Preparation of serum and patient}

There is a large variability in the preparation methodology, storage and dispensation of autologous serum eye drops. In addition, most authors agree on the need for standard criteria by means of multicentric randomized studies to optimize the results obtained with this treatment ${ }^{(5)}$. Blood is extracted from patient's vein with vacuum extraction tubes without anticoagulant. Subsequently, the tubes are left in 
vertical position at $22^{\circ} \mathrm{C}$ for about 2 hours to allow coagulation. After blood clot is formed, supernatant is centrifuged to separate the serum from the solid components. A bottle of serum eye drops with the desired concentration, adequately identified and preserved from light is given to the patient. It is important to keep the eye drops away from light because some of its components (vitamin A) degrade quickly with light exposure. Most prepared all the autologous serum eye drops with fresh serum, giving the flasks to the patients for their utilization, recommending them to keep the one in use in the refrigerator at $+4^{\circ} \mathrm{C}^{(5)}$. Regarding dispensation, some authors suggest a flask per day while others the same flask for one week ${ }^{(2,5)}$. The remaining bottles should be stored frozen (ideally at $-20^{\circ} \mathrm{C}$ ) for up to 3 months ${ }^{(2)}$. The number of applications varies from once every hour up to 3 times a day. Some authors believe that concentrations of $50 \%$ or $100 \%$ would have more effect on the eye surface ${ }^{(1,9)}$. However, the most standardized dilution of autologous serum is at $20 \%$ which is based on the concentration of certain growth factors in tears $^{(2,7)}$. It also seems to avoid the irritation derived from the higher viscosity in concentrated preparations and may act favorably by reducing the number of blood extraction procedures $^{(4)}$. Table 2 describes the variation in storage, preparation and application published in the literature.

\section{Indications}

Autologous serum has been utilized with varying success for managing numerous processes involving the corneal surface. Its successful application has been reported in the treatment of the following entities:

\section{Severe dry eye}

Dry eye syndrome is recognized as a growing public health problem and one of the most frequent reasons for seeking eye care. The estimated prevalence for people $\geq 50$ year-old in the United States is $7.8 \%$ for women (approximately 3.2 million affected), and $4.7 \%$ for men (approximately 1.6 million affected $)^{(10)}$. Dry eye syndrome is characterized by a deficiency in the quality or quantity of tears, an unstable tear film, ocular surface damage, and bothersome symptoms such as ocular irritation, grittiness, fatigue, and fluctuating vision $^{(11-12)}$.

Tananuvat et al. ${ }^{(13)}$ conducted a prospective, single-masked, placebo-controlled study in 12 patients with bilateral severe dry eye. One eye was randomized to receive $20 \%$ autologous serum as a tear substitute, and the fellow eye received unpreserved normal saline solution. There was a trend toward improvement in symptoms and signs of dry eye including favorable impression cytology changes in the autologous serum group, but this trend was not statistically significant.

Noble et al..$^{(1)}$ evaluated the efficacy of $50 \%$ autologous serum drops in Sjögren's syndrome (6 patients) and keratoconjunctivitis sicca (5 patients) in a prospective randomized crossover trial. Impression cytology showed significant improvement in the autologous serum $(\mathrm{P}<0.01)$, but no differen-

\begin{tabular}{|c|c|c|}
\hline & Tears & Serum \\
\hline $\mathrm{pH}$ & 7.4 & 7.4 \\
\hline Osmolarity & 298 & 296 \\
\hline EGF (ng/ml) & $0.2-3.0$ & 0.5 \\
\hline TGF- $\beta$ (ng/ml) & $2-10$ & $6-33$ \\
\hline Vitamin A (mg/ml) & 0.02 & 46 \\
\hline Lysozyme $(\mathrm{mg} / \mathrm{ml})$ & 1.4 & 6 \\
\hline $\lg A(\mu \mathrm{g} / \mathrm{ml})$ & 1190 & 2 \\
\hline Fibronectin $(\mu \mathrm{g} / \mathrm{ml})$ & 21 & 205 \\
\hline
\end{tabular}

\begin{tabular}{|c|c|}
\hline Production factor & Published variations \\
\hline Clotting phase & $0-2$ days \\
\hline Centrifugal force & $\begin{array}{l}1500 \mathrm{rpm}(300 \mathrm{~g}) \text { to } \\
4000 \mathrm{~g}(5000 \mathrm{rpm})\end{array}$ \\
\hline Duration of centrifugation & 5-20 minutes \\
\hline Dilution & $20 \%, 33 \%, 50 \%$, or $100 \%$ \\
\hline Diluent & $\begin{array}{l}0.9 \% \mathrm{NaCl}, \mathrm{BSS}, 0.5 \% \\
\text { chloramphenicol eye drops }\end{array}$ \\
\hline Container & $\begin{array}{l}1-6 \mathrm{ml} \text { in insulin } \\
\text { syringe or dropper bottle }\end{array}$ \\
\hline Storage & $-20^{\circ}$ to $+4^{\circ} \mathrm{C}$ \\
\hline $\begin{array}{l}\text { Number of daily applications } \\
\text { rpm }=\text { round per minute: } q=q \text { force }\end{array}$ & $\begin{array}{l}3 \text { times to hourly } \\
\text { alanced salt solution }\end{array}$ \\
\hline
\end{tabular}

ce was found in either rose bengal staining, Schirmer test, or tear clearance test. The crossover design of the study confirmed that these improvements were due to autologous serum drops, and that the beneficial effects were probably due to the presence of essential tear factors in the serum. For most of these patients, autologous serum was superior to conventional treatment for improving ocular surface health and subjective comfort.

Kojima et al. ${ }^{(14)}$ have evaluated the effectiveness of the $20 \%$ autologous serum eye drops in the treatment of severe dry eye patients. Thirty seven eyes ( 20 severe dry eye patients) without punctal occlusion were prospectively randomized in a case-control study. Group A patients used preservative-free artificial tears, and group $\mathrm{S}$ patients used autologous serum drops. The mean break-up time and fluorescein and rose bengal staining scores, as well as subjective symptoms scores, showed significant improvement in the patients assigned to autologous serum eye drops compared with subjects assigned to preservative-free artificial tears after 2 weeks of treatment. Based on these findings, autologous serum was found to be superior to conventional treatment with artificial tears for improving ocular surface health and subjective comfort.

Hyon et al. ${ }^{(15)}$ assessed the clinical efficacy of anti-inflammatory therapy in the management of primary Sjögren's syndrome in 38 patients. Anti-inflammatory therapy included 
topical corticosteroid, $20 \%$ topical autologous serum, and topical cyclosporine A. Subjective symptoms improved with anti-inflammatory treatment in $70 \%$ of patients with primary Sjögren's syndrome. Associated anti-inflammatory treatment provided significant improvement in visual acuity and fluorescein score but did not affect Schirmer score, tear break-up time, or rose bengal score. However, the authors did not find evidence that anti-inflammatory treatment increases tear production in patients with Sjögren's syndrome.

Recently, in 2008, Lee and Chen ${ }^{(16)}$ evaluated the efficacy and safety of long-term application of $20 \%$ autologous serum eye drops to treat recalcitrant dry eye syndrome. This is a retrospective chart review of 46 eyes of 23 patients in a followup period of 17.3 months (range 6 to 55 months). Corneal fluorescein staining of 34 eyes (73.9\%) showed improvement. Eighteen patients (35 eyes, 76.1\%) reported subjective improvement after using autologous serum eye drops. No significant complications were reported in this study.

\section{Persistent epithelial corneal defect}

Severe dry eye and neurotrophic ulcers present the most severe types of persistent epithelial defect (PED). Desiccation itself can be compensated by the frequent use of preservative-free artificial tears combined with the use of moisture chamber glasses, punctal plugs, or both. However, the lack of tear production results in the deprivation of essential tear components such as epidermal growth factor and vitamin A to the ocular surface epithelium ${ }^{(17)}$.

Tsubota et al. ${ }^{(17)}$ have shown the efficacy of autologous serum application for the treatment of PED. A non-comparative case series of 16 eyes was assessed prospectively. Autologous serum was prepared and diluted to $20 \%$ in saline, with a dosage of 6 to 10 times daily. Among all eyes with PED, 7 $(43.8 \%)$ healed within 2 weeks, $3(18.8 \%)$ healed within 1 month, and the remaining $6(37.5 \%)$ did not respond within 1 month. In summary, autologous serum application was effective in more than $60 \%$ of the cases of PED.

Young et al. ${ }^{(18)}$ studied retrospectively 10 eyes of 10 patients with PED treated with $20 \%$ autologous serum eye drops. The mean duration of PED before the treatment was 22.4 days. Six eyes healed within 2 weeks, but 2 eyes failed to heal after 1 month of treatment and 2 patients were lost from follow-up.

Alvarado Valero et al. ${ }^{(19)}$ studied the impact of topical treatment with $20 \%$ autologous serum on the clinical evolution of PED. In this prospective case series study of 17 eyes of 14 patients, the epithelial defect healed within 2 weeks in 6 eyes $(35.3 \%)$. Eight eyes $(47 \%)$ healed within 2 to 4 weeks and 3 eyes $(17.6 \%)$ did not heal after week 4 . The duration of PED, before serum therapy was 36 days. Six of 7 treated eyes presented an involution of squamous metaplasia 28 days after initiation of the autologous serum drops.

Schader et al. ${ }^{(20)}$ reported 6 eyes of 5 patients with PED which were treated with $20 \%$ autologous serum eye drops in combination with bandage contact lenses (BCL). All patients had been unsuccessfully treated with conventional therapy before. The PED healed in 5 of 6 eyes after a treatment period of $14.2 \pm 8.9$ days. In 1 eye the PED became smaller, but took 90 days until the lesion healed completely. These findings suggest that the combination of a BCL and autologous serum eye drops can be successfully used in the treatment of PED. Deposition of albumin may occur on the surface of the contact lenses, which, in the small group presented in this study, caused no unwanted effects.

\section{Recurrent corneal erosion}

Corneal erosions can be an extremely painful condition for many patients. The pathogenic mechanism is linked to abnormalities of the adhesion complex between the corneal epithelium and the stromal layer. The etiologies for erosions are very wide and include trauma, dry eye, corneal dystrophies, and eyelid diseases that occur after infection or spontaneously ${ }^{(21)}$. Holzer et al. ${ }^{(22)}$ evaluated the clinical outcomes after transepithelial phototherapeutic keratectomy (t-PTK) using an excimer laser and postoperative administration of $20 \%$ autologous serum eye drops to treat 25 eyes of 25 patients with 3 to 12 recurrent erosions. Postoperatively, autologous serum eye drops were administrated 6 times a day for 6 weeks. Twenty eyes $(80 \%)$ recovered without further corneal erosion in a follow-up period of 15.5 months (range 6 to 20 months). Five eyes had 1 further erosion, which was treated in 4 cases with autologous serum without additional excimer laser treatment. One patient requested additional tPTK treatment and recovered without further complications thereafter.

Del Castillo et al. ${ }^{(23)}$ studied the effect of $20 \%$ autologous serum in the treatment of recurrent corneal erosions in 11 eyes of 11 patients. Mean follow-up time was $9.4 \pm 3.7$ months (range, 4 to 16). Treatments prior to the use of autologous serum had failed to avoid recurrences in all patients, with the mean recurrence rate being 2.2 recurrences per month of follow-up. After the onset of serum treatment, only a single recurrence was recorded in 3 of the patients. Thus, the use of autologous serum for the treatment of patients with recurrent corneal erosion appears to be effective and safe in reducing the number of recurrences experienced by patients.

\section{Neurotrophic keratopathy}

Numerous ocular and systemic diseases, including viral keratitis, chemical or thermal burns of the ocular surface, fifth nerve palsy after removal of acoustic neuroma or radiation, drug toxicity, corneal surgery, multiple sclerosis, and diabetes, may lead to neurotrophic keratopathy (NK). This presents with a broad spectrum of corneal findings, including superficial punctate keratitis, epithelial defects, ulceration, and perforation. In neurotrophic ulcers, neural factors such as acetylcholine or substance $\mathrm{P}$ are depleted from the cornea. Nishida et al. ${ }^{(24)}$ emphasized the importance of substance $\mathrm{P}$ and insulin-like growth factor for a normal wound-healing response. 
Matsumoto et al. ${ }^{(25)}$ reported the treatment of 14 eyes of 11 patients with NK with application of $20 \%$ autologous serum eye drops 5 to 10 times daily until the defect healed. The epithelial defect healed completely in all eyes within 6 to 32 days (mean, $17.1 \pm 8.0$ days), with a decrease in corneal scarring. Corneal sensitivity, as measured by Cochet-Bonnet esthesiometer, increased from a pretreatment level of $11.8 \mathrm{~mm}$ to $30.0 \mathrm{~mm}$ after treatment at the last follow-up, and 5 eyes achieved normal corneal sensitivity with treatment. Moreover, the authors demonstrated that the best-corrected visual acuity improved in $78.6 \%$ of the eyes with treatment. Significantly increased concentrations of nerve growth factor, insulin-like growth factor, and substance $\mathrm{P}$ were noted in the serum tears that were not found in the patient's normal tear samples. It was concluded that autologous serum harbors neurotrophic factors and may provide neurologic healers for a compromised ocular surface.

\section{Filtering blebs after trabeculectomy}

Aqueous leakage from filtering blebs is not a rare condition after trabeculectomy with antimetabolites, which can pose a potential risk for bleb-related complication. Although the effects of serum on the conjunctiva have not been fully studied, vitamin A and epidermal growth factor are reported to have roles in maintaining the normal histology in the conjunctiva. Matsuo et al. ${ }^{(26)}$ evaluated the efficacy of $20 \%$ topical autologous serum application to stop aqueous oozing or point-leak through filtering bleb after trabeculectomy. A total of 21 eyes with oozing and 21 eyes with a point-leak through a functional bleb after trabeculectomy with 5-fluoracil or mitomycin $\mathrm{C}$ were enrolled in this randomized case-control study. The serum was topically applied 4 times a day for up to 12 weeks. In the serum and control groups, oozing stopped in $62.5 \%$ and $0 \%$ of eyes, respectively $(\mathrm{P}=0.003)$, and point-leaks stopped in 27.3 and $18.2 \%$, respectively $(\mathrm{P}>0.9)$. These findings suggest that autologous serum application was significantly effective to stop aqueous oozing but not point-leaks.

\section{Superior limbic keratoconjunctivitis}

Superior limbic keratoconjunctivitis (SLK) is a relatively uncommon ocular surface disorder, and mild clinical findings can cause a significant patient discomfort. Fine punctate rose bengal and fluorescein staining of the superior cornea and limbus are sometimes the only clinical signs detected. Its etiology is not completely understood, and various causes, such as eye rubbing, viral infection, and autoimmune diseases have been proposed, as well as a diverse range of possible treatments. Goto et al. ${ }^{(27)}$ assessed the efficacy of autologous serum drops in the treatment of SLK. Twenty two eyes of 11 SLK patients were treated with $20 \%$ autologous serum 10 times a day in addition to ongoing treatment of dry eye. Previous therapies, including artificial tears, topical corticosteroids, and topical vitamin A, were ineffective. Nine of the 11 patients reported subjective improvement $(81.8 \%)$, and all eyes showed objective improvement $(100 \%)$ by rose bengal or fluorescein staining. Despite the good results obtained in this study, the authors proposed that punctal occlusion be considered the first choice of therapy for SLK, and if conventional treatment is ineffective, autologous serum drops should be added to the regime.

\section{Graft-versus-host disease}

Allogeneic haematopoietic stem cell transplantation (SCT) is considered a curative treatment for various hematological malignancies. However, chronic graft-versus-host disease (GVHD) remains a major complication after SCT, and is the largest factor in impairing the quality of life of transplant recipients. Dry eye is one of the major symptoms of GVHD. Although several therapies have been used to minimize the symptoms of dry eyes associated with GVHD, an effective treatment has not been established. In 2000, Rocha et al. ${ }^{(28)}$ reported the first two cases of GVHD with severe dry eyes treated with autologous serum, which proved to be safe during the 10 months of treatment. Ogawa et al. ${ }^{(29)}$, in 2003, utilized autologous serum eye drops to treat 14 patients with severe dry eye associated with GVHD. The patients had been refractory to treatment with conventional artificial tears. A $20 \%$ solution of serum and sterile saline was applied 10 times a day. Mean follow-up was 19.4 months (range 4 to 41 months). After 4 weeks of treatment, significant improvement was observed in both complaint scores $(\mathrm{P}<0.01)$ and fluorescein scores $(\mathrm{P}<0.005)$. Significant improvements were observed also in rose bengal staining and tear break-up time. In 7 of 14 patients, the responses were maintained for 6 to 41 months, while 6 of the other 7 patients required treatment with punctal plugs in addition to autologous serum eye drops.

\section{Refractive surgery}

One of the most common complications of photorefractive keratectomy (PRK) and laser in situ keratomileusis (LASIK) is dry eye syndrome. Although dry eye after refractive surgery is usually transient, some patients complain of severe symptoms, which may negatively influence their satisfaction with the outcome of the procedure ${ }^{(30)}$. Both keratorefractive procedures have been reported to perturb the ocular surface homeostasis by causing a decrease in corneal sensitivity ${ }^{(31)}$, tear film instability, decreased aqueous tear production, and corneal and conjunctival epitheliopathy ${ }^{(30)}$.

Noda-Tsuruya et al. ${ }^{(32)}$ evaluated the efficacy of $20 \%$ autologous serum eye drops for dry eye after LASIK. Fiftyfour eyes that underwent LASIK were divided into two groups; patients who used autologous serum eye drops and those who used artificial tears postoperatively. The results showed that break-up time test and vital staining were significantly improved in the autologous serum eye drops group, whereas no change was reported in the artificial tear group at 6 months postoperatively. These findings suggest that autologous serum eye drops could be effective for postoperative dry eye induced by LASIK. 
Toda et al. ${ }^{(33)}$ performed LASIK in three patients who suffered from Sjögren's syndrome and showed decreased reflex tearing. They inserted punctal plugs and prepared the 20\% autologous serum at the first visit of each patient. The procedure was scheduled to be undertaken after the ocular surface damage was healed by the treatment. LASIK was then performed uneventfully, and no complications were observed in any of the patients. These results indicate that LASIK may be safely performed on patients with severe dry eye, if the ocular surface damage is aggressively treated before surgery.

\section{Aniridic keratopathy}

Keratopathy occurs in $20 \%$ to $90 \%$ of patients with aniridia and is caused by a primary dysfunction of the limbal stem cells. Corneal changes include recurrent erosions and ulcerations of corneal epithelium, tear film instability, dry eye, chronic pain, corneal vascularization, progressive corneal opacification, and blindness. López-García et al. ${ }^{(34)}$ studied the effect of $20 \%$ autologous serum eye drops in a prospective case series of 26 eyes of 13 patients with aniridic keratopathy. The mean age of the patients was $26 \pm 9.5$ years (range 9 to 48 years). There were no local side effects from autologous serum treatment, and all patients showed a subjective improvement of keratopathy symptoms after the serum application. The corneal reepithelialization, corneal epithelial cell squamous metaplasia, and tear stability improved significantly with the treatment, but visual acuity, regression of vascular pannus, and subepithelial scarring showed only slight improvement.

\section{Ocular surface reconstruction}

Ocular cicatricial pemphigoid and Stevens-Johnson syndrome are severe ocular surface diseases of unknown origin that often result in bilateral blindness, despite such treatment as immunosuppression. Although penetrating keratoplasty is an established procedure for the accompanying conditions, including severe dry eye, lack of corneal stem cells, trichiasis, and persistent ocular surface inflammation, make these diseases refractory to treatment. Tsubota et al. ${ }^{(35)}$ evaluated 14 eyes of 11 patients with cicatricial keratoconjunctivitis (7 patients with cicatricial pemphigoid and 4 with StevensJohnson syndrome). The patients were treated with a combination of allograft limbal transplantation, amniotic membrane transplantation, and tarsorrhaphy, followed every 15 minutes by $20 \%$ autologous serum eye drops. Eight patients required concomitant penetrating or lamellar keratoplasty because of corneal opacity. With a mean follow-up of 143 days (range 10 to 608 days), the authors achieved successful ocular surface reconstruction in 12 eyes $(86 \%)$, with minimal recurrence of symblepharon. However, failure occurred in 2 eyes that developed corneal infiltrations and vascularization.

\section{Mooren's ulcer}

Mooren's ulcer is an uncommon, inflammatory keratopathy characterized by severe pain, conjunctival and episcle- ral injection, and peripheral corneal ulceration. The corneal changes may expand centrally or peripherally producing dramatic corneal thinning, often with an overhanging edge of superficial cornea. One or both eyes may be affected and recurrences are common. Most cases resolve with stromal thinning and scarring, although a minority of cases advance to perforation. Its clinical course and eventual prognosis is variable and usually these ulcers respond poorly to conventional therapy. Mavrakanas et al. ${ }^{(36)}$ reported a case of Mooren's ulcer treated with antibiotic, corticosteroid and cyclosporine therapy. The patient did not respond well to initial treatment, but reepithelialization occurred and the corneal deficit improved after the introduction of $20 \%$ autologous serum eye drops. Therefore, autologous serum appears to be an effective supplementary treatment in Mooren's ulcer, by providing enhanced conditions for epithelial healing and by modulating the corneal inflammatory and immune response.

\section{Stability, drawbacks, potential risks, complications, and patient information}

\section{Stability}

Regarding stability, Tsubota et al. ${ }^{(7)}$ reported that the concentration of growth factors, vitamin $\mathrm{A}$, and fibronectin in $100 \%$ and $20 \%$ serum diluted with $\mathrm{NaCl}$ stored at $+4{ }^{\circ} \mathrm{C}$ remained unchanged for 1 month and at $-20^{\circ} \mathrm{C}$ for at least 3 months. However, no more detailed published evidence is available to clarify the minimum freezer temperature required for several months of storage. Leite et al..$^{(37)}$ analyzed viability of autologous serum by the presence of insulin and protein levels. The authors found insulin levels in autologous serum of $2.30 \pm 0.60(n=9)$ at day 0 and $1.60 \pm 0.70 \mathrm{ng} / \mathrm{ml}$ $(n=5)$ at day $30(\mathrm{P}=0.84)$. The protein levels were $51.10 \pm 2.70$ at day $0(\mathrm{n}=9)$ and $50.70 \pm 4.60 \mathrm{ng} / \mathrm{ml}$ at day $30(n=5)$ $(\mathrm{P}=0.47)$.

\section{Drawbacks of serum eye drops treatment}

Since autologous serum preparation is a body fluid, it is able to transmit infections ${ }^{(2)}$. Another drawback of autologous serum treatment lies in the frequent blood extractions, mainly in the groups requiring prolonged treatment. In these cases, it is important to pay attention because not all patients can be treated due to systemic difficulties and in some occasions it is even necessary to provide an iron sulphate supplement to prevent anemia ${ }^{(5)}$. Autologous serum contains no preservatives, which avoids the risk of preservative toxicity, however, there is a potential risk of inducing infections because of microbial contamination of the dropper bottle ${ }^{(16)}$. Leite et al. ${ }^{(37)}$ analyzed 11 autologous serum samples after 30 days of use by the patients, in which 6 of them were contaminated by single or multiple microorganisms such as: Klebsiella pneumoniae (4/6), Streptococcus viridans (3/6), Candida sp (1/6), Pseudomonas aeruginosa (1/6), Bacillus sp (1/6), Staphylococcus aureus (1/6), Micrococcus sp (1/6). 


\section{Complications}

The literature describes some complications such as the deposit of immunoglobulins in the cornea and the presence of corneal peripheral infiltrates with $100 \%$ autologous serum treatment in one patient ${ }^{(38)}$. The literature does not describe either side effect when utilized for long periods of time. Autologous serum treatment is usually well tolerated and most patients report improvement of discomfort sensation. Although uncommon, some patients may experience increased discomfort, slight epitheliopathy, bacterial conjunctivitis or eyelid eczema, according to some reports ${ }^{(5)}$.

\section{Standardizing the production of serum eye drops}

Neither production nor application of serum have been standardized so far. It also remains unclear whether the serum should be filter-sterilized to remove any corpuscular blood components. The variable efficacy of serum eye drops suggests that the parameters for their production should be standardized and optimized before any meaningful placebo controlled randomized clinical trial can evaluate the real potential of this therapy ${ }^{(2)}$.

\section{Quality control and patient information}

The use of autologous serum requires proper preparation of the serum formulation with adequate informed consent and education of the patient. The patient should be informed of the risks of infection and the need to maintain the vials properly refrigerated to minimize contamination.

In case of homologous use and to reduce the risk of infection from diseases transmitted through blood, it is strongly recommended that the donor be tested for blood-transmitted diseases such as HIV, hepatitis B virus, hepatitis C virus, and syphilis ${ }^{(39)}$. Bacterial contamination is a potential risk in the production and use of serum eye drops. Sterile manufacturing conditions, beginning with thorough skin disinfection, are very important. A microbiological examination of the product should be performed before application in order to rule out bacterial contamination resulting from the production process ${ }^{(2)}$.

\section{CONCLUSIONS}

Treatment with autologous serum is an efficient method to provide a number of growth factors that have been reduced by ocular surface disorders. There is some medical evidence that autologous serum might be clinically effective in some particular ocular surface diseases compared to standard treatment. Moreover, both treatments can supplement each other, thus reducing artificial tear dependency.

\section{RESUMO}

O soro autólogo tem sido adotado como uma nova abordagem para tratar síndrome do olho seco porque contém vitaminas, alguns fatores de crecimento e fibronectina que são considerados importantes contribuintes para integridade corneana e conjuntival. Colírio de soro autólogo é produzido sem preservativo. O soro é não-alérgico e suas propriedades bioquímicas são similares à lágrima. $\mathrm{O}$ soro autólogo tópico tem sido relatado efetivo para o tratamento de olho seco grave relacionado a distúrbios da superfície ocular como na síndrome de Sjögren, ceratoconjuntivite límbica superior, doença do enxerto versus hospedeiro, síndrome de Stevens-Johnson, procedimentos cerato-refrativos, erosão corneana persistente ou recorrente, ceratopatia neurotrófica, úlcera de Mooren, ceratopatia associada à aniridia, e bolhas filtrantes após trabeculectomia. O objetivo do presente estudo é revisar a literatura recentemente publicada sobre doenças da superficie ocular tratadas com soro autológo tópico.

Descritores: Doenças da córnea/terapia; Doenças da conjuntiva/terapia; Aparelho lacrimal/anormalidades; Soro; Soluções oftálmicas/uso terapêutico

\section{REFERENCES}

1. Noble BA, Loh RS, MacLennan S, Pesudovs K, Reynolds A, Bridges LR et al. Comparison of autologous serum eye drops with conventional therapy in a randomized controlled crossover trial for ocular surface disease. Br J Ophthalmol. 2004;88(5):647-52.

2. Geerling G, Maclennan S, Hartwig D. Autologous serum eye drops for ocular surface disorders. Br J Ophthalmology. 2004;88(11):1467-74.

3. Liu L, Hartwig D, Harloff S, Herminghaus P, Wedel T, Geerling G. An optimised protocol for the production of autologous serum eyedrops. Graefes Arch Clin Exp Ophthalmol. 2005;243(7):706-14

4. Koffler BH. Autologous serum therapy of the ocular surface with novel delivery by platelet concentrate gel. Ocul Surf. 2006;4(4):188-95.

5. López-García JS, García-Lozano I, Rivas L, Martínez-Garchitorena J. Use of autologous serum in ophthalmic practice. Arch Soc Esp Oftalmol. 2007; 82(1):9-20

6. Fox RI, Chan R, Michelson JB, Belmont JB, Michelson PE. Beneficial effect of artificial tears made with autologous serum in patients with keratoconjunctivitis sicca. Arthritis Rheum. 1984;27(4):459-61.

7. Tsubota K, Goto E, Fujita H, Ono M, Inoue H, Saito I, Shimmura S. Treatment of dry eye by autologous serum application in Sjögren's syndrome. Br J Ophthalmol. 1999;83(4):390-5.

8. Lagnado R, King AJ, Donald F, Dua HS. A protocol for low contamination risk of autologous serum drops in the management of ocular surface disorders. Br J Ophthalmol. 2004;88(4):464-5.

9. Poon AC, Geerling G, Dart JK, Fraenkel GE, Daniels JT. Autologous serum eyedrops for dry eyes and epithelial defects: clinical and in vitro toxicity studies. Br J Ophthalmol. 2001;85(10):1188-97.

10. Schaumberg DA, Sullivan DA, Buring JE, Dana MR. Prevalence of dry eye syndrome among US women. Am J Ophthalmol. 2003;136(2):318-26.

11. Behrens A, Doyle JJ, Stern L, Chuck RS, McDonnell PJ, Azar DT et al. Dysfunctional tear syndrome - a Delphi approach to treatment recommendations. Cornea. 2006;25(8):900-7.

12. The definition and classification of dry eye disease: report of the Definition and Classification Subcommittee of the International Dry Eye WorkShop (2007). Ocul Surf. 2007;5(2):75-92.

13. Tananuvat N, Daniell M, Sullivan LJ, Yi Q, McKelvie P, McCarty DJ et al. Controlled study of the use of autologous serum in dry eye patients. Cornea. 2001;20(8):802-6.

14. Kojima T, Ishida R, Dogru M, Goto E, Matsumoto Y, Kaido M, Tsubota K. The effect of autologous serum eye drops in the treatment of severe dry eye disease: a prospective randomized case-control study. Am J Ophthalmol. 2005;139(2):242-6.

15. Hyon JY, Lee YJ, Yun PY. Management of ocular surface inflammation in Sjögren syndrome. Cornea. 2007;26(9 Suppl 1):S13-15. 
16. Lee GA, Chen SX. Autologous serum in the management of recalcitrant dry eye syndrome. Clin Experiment Ophthalmol. 2008;36(2):119-22.

17. Tsubota K, Goto E, Shimmura S, Shimazaki J. Treatment of persistent corneal epithelial defect by autologous serum application. Ophthalmology. 1999;106(10):1984-9.

18. Young AL, Cheng AC, Ng HK, Cheng LL, Leung GY, Lam DS. The use of autologous serum tears in persistent corneal epithelial defects. Eye. 2004; 18(6):609-14.

19. Alvarado Valero MC, Martínez Toldos JJ, Borras Blasco J, Almiñana Almiñana A, Pérez Ramos JM. Treatment of persistent epithelial defects using autologous serum application. Arch Soc Esp Oftalmol. 2004;79(11):537-42.

20. Schrader S, Wedel T, Moll R, Geerling G. Combination of serum eye drops with hydrogel bandage contact lenses in the treatment of persistent epithelial defects. Graefes Arch Clin Exp Ophthalmol. 2006;244(10):1345-9.

21. Reidy JJ, Paulus MP, Gona S. Recurrent erosions of the cornea: epidemiology and treatment. Cornea. 2000;19(6):767-71.

22. Holzer MP, Auffarth GU, Specht H, Kruse FE. Combination of transepithelial phototherapeutic keratectomy and autologous serum eyedrops for treatment of recurrent corneal erosions. J Cataract Refract Surg. 2005;31(8):1603-6.

23. Del Castillo JM, de la Casa JM, Sardiña RC, Fernández RM, Feijoo JG, Gómez AC et al. Treatment of recurrent corneal erosions using autologous serum. Cornea. 2002;21(8):781-3.

24. Nishida T, Nakamura M, Ofuji K, Reid TW, Mannis MJ, Murphy CJ. Synergistic effects of substance $\mathrm{P}$ with insulin-like growth factor-1 on epithelial migration of the cornea. J Cell Physiol. 1996;169(1):159-66.

25. Matsumoto Y, Dogru M, Goto E, Ohashi Y, Kojima T, Ishida R, Tsubota K. Autologous serum application in the treatment of neurotrophic keratopathy. Ophthalmology. 2004;111(6):1115-20.

26. Matsuo H, Tomidokoro A, Tomita G, Araie M. Topical application of autologous serum for the treatment of late-onset aqueous oozing or point-leak through filtering bleb. Eye. 2005;19(1):23-8.

27. Goto E, Shimmura S, Shimazaki J, Tsubota K. Treatment of superior limbic keratoconjunctivitis by application of autologous serum. Cornea. 2001; 20(8):807-10.
28. Rocha EM, Pelegrino FS, de Paiva CS, Vigorito AC, de Souza CA. GVHD dry eyes treated with autologous serum tears. Bone Marrow Transplant. 2000; 25(10):1101-3.

29. Ogawa Y, Okamoto S, Mori T, Yamada M, Mashima Y, Watanabe R et al. Autologous serum eye drops for the treatment of severe dry eye in patients with chronic graft-versus-host disease. Bone Marrow Ophthalmol. 2003; 31(7):579-83.

30. Quinto GG, Camacho W, Behrens A. Postrefractive surgery dry eye. Curr Opin Ophthalmol. 2008;19(4):335-41.

31. Campos M, Hertzog L, Garbus JJ, McDonnell PJ. Corneal sensitivity after photorefractive keratectomy. Am J Ophthalmology. 1992;114(1):51-4.

32. Noda-Tsuruya T, Asano-Kato N, Toda I, Tsubota K. Autologous serum eye drops for dry eye after LASIK. J Refract Surg. 2006;22(1):61-6.

33. Toda I, Asano-Kato N, Hori-Komai Y, Tsubota K. Ocular surface treatment before laser in situ keratomileusis in patients with severe dry eye. J Refract Surg. 2004;20(3):270-5.

34. López-García JS, Rivas L, García-Lozano I, Murube J. Autologous serum eyedrops in the treatment of aniridic keratopathy. Ophthalmology. 2008;115(2): 262-7.

35. Tsubota K, Satake Y, Ohyama M, Toda I, Takano Y, Ono M et al. Surgical reconstruction of the ocular surface in advanced ocular cicatricial pemphigoid and Stevens-Johnson syndrome. Am J Ophthalmol. 2006;122(1):38-52.

36. Mavrakanas NA, Kiel R, Dosso AA. Autologous serum application in the treatment of Mooren's ulcer. Klin Monatsbl Augenheilkd. 2007;224(4): $300-2$.

37. Leite SC, de Castro RS, Alves M, Cunha DA, Correa ME, da Silveira LA et al. Risk factors and characteristics of ocular complications, and efficacy of autologous serum tears after haematopoietic progenitor cell transplantation. Bone Marrow Transplant. 2006;38(3):223-7.

38. McDonnell PJ, Schanzlin DJ, Rao NA. Immunoglobulin deposition in the cornea after application of autologous serum. Arch Ophthalmol. 1988;106(10): 1423-5.

39. Weisbach V, Dietrich T, Kruse FE, Eckstein R, Cursiefen C. HIV and hepatitis $\mathrm{B} / \mathrm{C}$ infections in patients donating blood for use as autologous serum eye drops. Br J Ophthalmol. 2007;91(12):1724-5. 